\title{
Važnost epideiktičkoga žanra u klasičnoj i suvremenoj retorici
}

\author{
(Na primjeru analize božićnih poruka \\ hrvatskih biskupa)
}

\author{
GABRIJELA KIŠIČEK* \\ • https://doi.org/10.31823/d.27.2.5 • \\ UDK: 808.5*2-475(497.5) • Pregledni članak \\ Primljeno: 14. srpnja 2018. • Prihvaćeno: 13. lipnja 2019. \\ »Snaga riječi u odnosu na duh \\ ista je kao što je to lijek u odnosu na tijelo.« \\ (Georgius de Sclavonia)
}

Sažetak: U radu se daje pregled povijesnoga razvoja $i$ važnosti epideiktičkoga žanra u retorici. Aristotel je retoriku podijelio na deliberativnu, sudsku i epideiktičku, razlikujući ih međusobno prema cilju kojem teže, prema načinima argumentiranja, prema dominantnom sredstvu uvjeravanja te prema vremenskoj usmjerenosti (deliberativno govorništvo usmjereno

${ }^{*}$ Doc. dr. sc.

Gabrijela Kišiček, Filozofski fakultet Sveučilišta u Zagrebu, Ivana Lučića 3, 10000 Zagreb, gkisicek@ffzg.hr je na budućnost, sudsko na prošlost, a epideiktičko na sadašnjost). $U$ radu se iznose retoričke specifičnosti epideiktičkoga žanra te se naglašava važnost $i$ vrijednost te vrste govorništva $i$ u klasičnoj $i$ u suvremenoj retorici. Kao primjer aktualne prisutnosti epideiktičke retorike analiziraju se božićne poruke hrvatskih biskupa kako bi se na konkretnim primjerima pokazalo kako epideiktičko govorništvo izgleda u suvremenoj praksi, ali istovremeno se opisuju i božićne poruke kao jedna specifična i posebna govornička vrsta kršćanske retorike.

Ključne riječi: epideiktička retorika, deliberativna retorika, patos, božićne poruke.

\section{Uvod}

Poznato je kako Aristotel u svojoj Retorici razlikuje deliberativno ili političko govorništvo usmjereno na donošenje odluka, a koje se bavi pitanjima korisnosti (sumpheron) ili 
štetnosti (blaberon) u temama kao što su zakonodavstvo, odluke o ratu i miru, trgovini i općenito svim općedruštvenim pitanjima. Druga vrsta govora jest forenzičko ili sudsko govorništvo kojem je cilj utvrđivanje krivnje, odnosno nevinosti pojedinca. Aristotel ${ }^{1}$ ističe kako je u sudskom govorništvu za uspjeh važno da govornik u obzir uzme opća mjesta, stavove i vjerovanja sudaca (endoxa), njihova poimanja motiva i različitih karaktera. Treća vrsta govora o kojima Aristotel piše jesu epideiktički govori kojima će se u ovom radu posvetiti najviše pozornosti.

U epideiktičkoj retoričkoj vrsti govornik neku osobu ili događaj hvali ili kritizira imajući u vidu ponajprije sadašnjicu. Međutim često poseže i za prošlošću (evocirajući uspomene iz prošlosti), ali i za budućnošću (nastoji predvidjeti budući događaj). Govornikov cilj jest obrazložiti da su radnje koje u svom govoru hvali, doista, uzvišene, vrijedne i ispunjene vrlinama te potaknuti publiku da poštuje i slavi ono što je dobro, a osudi ono loše.

Epideiktičko govorništvo u praksi ima tradiciju dugu više od 25 stoljeća, a sustavno ga opisuje Aristotel $^{2}$ u prvoj knjizi Retorike (IX. poglavlje). Aristotel daje definiciju vrline i općenito objašnjava koncept hvalevrijednoga. Vrlina [arete] je prema Aristotelu sposobnost [dynamis] da se čini dobro, odnosno znači: činiti dobro na dobar način u svim sferama života. Epideiktičko je govorništvo usmjereno na to da hvali određene osobine pa Aristotel daje svojevrstan popis tema koje govorniku mogu poslužiti u epideiktičkome govorništvu. Govoreći o tom retoričkom žanru, ističe kako se epideiktičke premise vrlo lako mogu pretvoriti u deliberativne ako se primjene na savjete koje je potrebno slijediti u budućnosti. Osobine koje, prema Aristotelu, valja hvaliti, među ostalima, jesu: pravednost, hrabrost, samokontrola, slobodoumnost, nježnost, mudrost. Svaku osobinu objašnjava te iznosi njezinu suprotnost. Vrlinama i njihovim suprotnostima Aristotel se detaljnije bavio u Nikomahovoj etici. Sam naziv epideiktičko dolazi od grčke riječi epideixis što doslovno znači 'pokazati, iskazati, demonstrirati'. Carey ${ }^{3}$ navodi kako se od deliberativnoga i sudskoga govorništva razlikuje po tome što nema izravni, očiti učinak jer se u skupštinama i sudnicama očekivala jasna odluka, pobijediti ili izgubiti u raspravi, a što sa sobom nosi vidljive, praktične posljedice, dok takvih očitih i neposrednih posljedica kod epideiktičkih govora nema. Oni su bili karakteristični za javne svečanosti kao što su pogrebi, proslave, obljetnice, komemoracije ratnim herojima. U epideiktičkom govorništvu cilj je pohvaliti osobe koje se ističu nekim vrlinama, a u rijet-

\footnotetext{
${ }^{1}$ Usp. A. OKSENBERB RORTY, 1996. Structuring Rhetoric, u: ISTI (ur.), Esseys on Aristotle's Rhetoric, Berkley, 1996., 4.

${ }^{2}$ Usp. ARISTOTEL, On Rhetoric, Oxford, 1991.

${ }^{3}$ C. CAREY, Epideictic Oratory, u: I. WORTHINGTON (ur.), A Companion to Greek Rhetoric, Malden, 2010., 237.
} 
kim prigodama i koriti one koji su učinili nešto loše. Oksenberg Rorty ${ }^{4}$ piše o Aristotelovu tumačenju epideiktičkoga govorništva ističući kako je ono samo na prvi pogled površno i tipično ceremonijalno. Naime epidekitičkim govorništvom obraćamo se široj publici radi isticanja vrijednosti, pohvale vrlinama i pokude porocima i slabostima. A s obzirom na to da se uglavnom bavi temama koje nisu diskutabilne, amplifikacija (auxesis) je najprimjereniji način argumentiranja. Cilj je uvjeriti publiku da hvali vrline koje su plemenite i poželjne, a osuđuje i odbacuje one koje su sramotne. No Aristotel, shvaćajući praktičnu, ali i pedagošku funkciju epideiktičke retorike, ističe njezinu vrijednost, važnost te velik utjecaj na deliberativnu retoriku smatrajući kako isticanje određenih vrijednosti utječe na buduće akcije. Epideiktički govor dakle pribjegava amplifikaciji, figuri koja $\gg$ neko obilježje nastoji proširiti na ukupnost izrečenoga $\ll^{5}$. Međutim Aristotel ${ }^{6}$ drži da figura preuveličavanja najbolje pristaje epideiktičkim govorima jer tu govornik hvali djela koja nitko ne osporava. Kao oblik uvjeravanja koristi patos koji djeluje na emocije publike. Međutim još u razdoblju antičke Grčke Atenjani su pomalo zanemarivali i odbacivali epideiktičke govore smatrajući ih trivijalnim i samodostatnim. Worthington ${ }^{7}$ navodi Izokratove riječi prema kojima ljudi nisu svjesni da se sudski i politički govori bave ozbiljnim pitanjima koja zahtijevaju hitnu raspravu. No, unatoč svojem katkada negativnom tonu, Izokrat je poput svojih suvremenika ozbiljno shvatio važnost epideiktičkih govora zbog toga što neposrednost ishoda ne znači nepostojanje praktičnih ciljeva. Osim činjenice da su se izvodili u različitim prigodama, epideiktički su govori postali važan dio grčke svakodnevice. I u današnje se vrijeme primjećuje znatna važnost epideiktičkih govora. Worthington ${ }^{8}$ se poziva na riječi J. Walkera da su retorika i poezija neraskidivo povezane, a ta je veza stoljećima najvidljivija u epideiktičkom diskursu te ističe važnost epideiktičkih govora kao sredstva u kojem se najbolje ocrtava govornikova elokvencija, bilo da je riječ o javnim ili privatnim govorima.

\section{Povijesni razvoj epideiktičkoga žanra}

Kada je Periklo 441. godine prije Krista održao govor Palim Atenjanima, započeo je s retoričkom tradicijom govora kojima se slave i uzdižu određene vrijednosti, a u iznimnim slučajevima kude i kritiziraju poroci. Nakon Peloponeskoga rata Periklo je želio odati počast svim poginulim Atenjanima ističući vrijednosti kao što su hra-

\footnotetext{
${ }^{4}$ Usp. A. OKSENBERG RORTY, 1996. Structuring Rhetoric, 3.

${ }^{5}$ M. MEYER, M. CARRIHLO, B. TIMMERMANS, Povijest retorike od Grka do naših dana, Zagreb, 39.

${ }^{6}$ ARISTOTEL, Retorika, Zagreb, 1989.

${ }^{7}$ Isto, 124.

${ }^{8}$ Isto, 138.
} 
brost, požrtvovnost, borba za slobodu, plemenitost i odvažnost, čast i dostojanstvo. Atenjani su $\gg$ u toj obrani držali da im treba radije i smrt pretrpjeti nego uzmaknuti i spasiti se $\ll^{9}$, a oni koji su ostali iza njih slavit će ih, divit će im se (»Divit će nam se sadašnji svijet i kasniji naraštaji $\ll$ ), nikada ih ne će zaboraviti i vječno će im biti zahvalni na slobodi koju su omogućili Ateni. Time Periklo jasno šalje poruku i onima koji ostaju. Junaštvo se nikada ne smije zaboraviti: »Gdje su, naime, za hrabrost ustanovljene najveće nagrade, ondje su i građani najbolji ljudi $\ll{ }^{10}$.

Prema Wohringtonu ${ }^{11}$ posmrtni su govori u antičko vrijeme bili najčešći. Kada bi netko poginuo u ratu, njegovo bi se tijelo spaljivalo na bojištu, a njegovi ostatci prenosili bi se u rodni grad. Na kraju svake ratne godine održavao se posmrtni govor za sve poginule. Iz toga su razloga posmrtni govori bili vrlo važni, čak su predstavljali poseban žanr epideiktičkih govora. Bili su prepoznatljivi po nizu tema koje su se ponavljale i po specifičnom odnosu govornika i publike koji se temeljio na uzajamnom priznavanju i veličanju hrabrosti i uspjeha poginulih.

Vrijedno je spomenuti i posmrtni govor čije autorstvo ne možemo točno utvrditi, iako ga neki pripisuju Demostenu. Riječ je o posmrtnom govoru održanom 338. g. pr. Kr. u čast poginulih u bitci kod Koroneje, nakon koje je Atena prestala biti središte političke moći. U povijesti retorike naziva se Govor 60, a spominje se kako Dionizije iz Halikarnasusa već sumnja u Demostenovo autorstvo, što mnogi moderni autori prihvaćaju. Iako govor sadrži demostenska obilježja, što se vidi u manevriranju frazama, iako ima dobrih dijelova, povjesničari su taj govor okarakterizirali kao slab jer iz njega ne proizlazi jasna moralna slika društva ni utjecaj na publiku. Ipak, zbog važnosti u povijesnom i u retoričkom kontekstu govor se često navodi kao tipičan primjer epideiktičkoga posmrtnoga govora.

Međutim među svim poznatim posmrtnim govorima iz toga doba posebno je zanimljiv posmrtni govor kojim Homer završava svoju Ilijadu. Zanimljiv je jer je održan u čast triju žena, a u to je vrijeme žena rijetko kada bila u središtu radnje i općenito se vrlo malo značenje pridavalo ženama. U Homerovoj Ilijadi, ipak, Hektor drži posmrtni govor u čast Helene, Andromahe i Hekube. ${ }^{12}$

Također među antičkim posmrtnim govorima valja spomenuti i onaj Hiperida $u$ čast palim vojnicima u Lamijskom ratu. Govor je specifičan zato što predstavlja svojevrstan otklon od uobičajene retoričke forme i sadržaja tadašnjih govora. Primjerice izostavlja korištenje mitoloških općih mjesta i posvećuje se stvarnim po-

\footnotetext{
${ }^{9}$ I. ZADRO (prir.), Glasoviti govori, Zagreb, 2001., 13.

${ }^{10}$ Isto, 14.

${ }^{11}$ I. WORGINGTON, Persuasion: Greek Rhetoric in Action, New York, 2013., 241.

${ }^{12}$ Isto, 243.
} 
vijesnim događajima. Posebnu pozornost daje poginulom vojnom zapovjedniku Leostenu. Taj je govor izazvao veliko divljenje jer je bio izravan, iskren i duboko emotivan. U usporedbi s Periklovim govorom očita je razlika u stilu. Periklov je stil građanski, filozofski i strog, dok je Hiperidov osoban, povijestan i emotivan. Dakle treba istaknuti kako je ta vrsta govora odigrala važnu ulogu u tada aktualnim problemima atenskoga društva jer se kroz epideiktičke govore jačala moralna svijest cjelokupnoga atenskoga društva. Pripadnici sofističkoga smjera razvili su pojam epideixis koji je označavao govore posebno pripremljene za formalne prigode. Takve su govore pripremali polaznici tadašnjih mnogobrojnih sofističkih škola. Najznačajniji predstavnik sofista među čijim su se radovima nalazili epideiktički ili pohvalni govori za razne prigode jest Gorgija. Govoreći o uvjeravanju, posebnu je pozornost posvetio $z v u k u$ riječi, tj. dojmu koji je korištenje određenom riječju ostavljalo na slušatelja. Vjerovao je da zvuk riječi, kada se kombinira s drugim retoričkim vještinama, može utjecati na publiku i privući njezinu pozornost. Njegov najpoznatiji epideiktički govor bio je Pohvala Heleni, kojim hvali Helenu Trojansku zbog njezine hrabrosti da s Parisom pobjegne u Spartu. ${ }^{13}$ Govori o njezinoj nadmoći nad svim muškarcima i ženama među kojima je živjela, o tome koliko se isticala svojom izvanrednošću te ju uspoređuje sa samim Zeusom. Braneći Helenu, Gorgija istovremeno naglašava moć koju govor ima nad ljudima te iznosi svojevrsnu pohvalu retorici. »Onaj govor, naime, koji je uvjerio i nagovorio njezinu dušu, nuždom ju je prisilio da vjeruje izrečenim riječima i pristane na gotova djela. Nepravda se stoga može pripisati samo onomu koji je dušu nagovorio, zato što je na nju izvršio nužan pritisak, dok je nagovorena duša otrpjela nužan utjecaj govora, pa je uzalud i s krivom optužujemo. ${ }^{14}$ Figure kojima se Gorgija služio u svojim govorima snažno su i zavodljivo djelovale na publiku. Kennedy ${ }^{15}$ piše kako se upravo zbog tih specifičnih tehnika kojima je budio strasti kod publike na njega često referiralo kao nekoga tko govorom stvara magiju. I upravo zbog te zavodljive slatkorječivosti nikada nije smatran filozofom, već samo retoričarem (u onom pejorativnom, platonovskom poimanju retorike). Epideiktičko je govorništvo, kao što se vidi iz Gorgijeva primjera, od svojih najranijih početaka bilo na rubu toga pejorativnoga, zavodljivoga, magičnoga. Također kao antički primjer epideiktičkoga govora služi i Izokratova Pohvala Evagori, prvi epideiktički govor pisan kao prozni tekst, a koji slavi vrline kralja, njegove uspjehe i intelektualne osobine, njegovu humanu vladavinu i ostavštinu. ${ }^{16}$ Ipak, treba istaknuti kao što piše i Herrick ${ }^{17}$, epideiktičko govorništvo šire

\footnotetext{
${ }^{13}$ Usp. J. HERRICK, The History and Theory of Rhetoric, Boston, 2005., 40.

${ }^{14}$ M. MEYER i dr., Povijest retorike od Grka do naših dana, 21.

${ }^{15}$ G. KENNEDY, A New History of Classical Rhetoric, Princeton, 1980., 30.

${ }^{16}$ Usp. Y. LEE TOO, Epideictic Genre, u: T. SLOANE (ur.), Encyclopedia of Rhetoric, Oxford, 2006.

${ }^{17}$ Usp. J. HERRICK, The History and Theory of Rhetoric, 84.
} 
je nego što nam se to u prvi mah čini. Naime svaki put kad razmišljamo i kad govorimo pohvalno o nekome ili nečemu, kad obrazlažemo nešto što smatramo dobrim, plemenitim, hrabrim itd., mi smo u području epideiktičkoga. U Platonovoj Gozbi Fedar iznosi pohvalu Erosu kao jednom od najstarijih i najčasnijih bogova. Također hvali i one koji su pošli u smrt zbog ljubavi: Alkestidu, Orfeja, Patrokla i Ahileja. U nastavku nalazimo i Agatonovu pohvalu Erosa u kojoj ističe njegovo blaženstvo, a zatim nabraja i darove koje im je dao. ${ }^{18}$ Krajem helenističkoga razdoblja Aristotelov učenik Teofrast podijelio je epideiktički govor prema vrstama. Tako su se razlikovali posmrtni govori (epitaphios logos), carski (imperijalistički) govori (basilikos logos), govori povodom vjenčanja (epithalamios), povodom rođendana (genethliakos) i mnogi drugi. Prema Herricku ${ }^{19}$, G. Kennedy, proučavajući astečku retoriku, pronašao je nešto nalik antičkim epideiktičkim govorima koji su u astečkoj kulturi bili podjednako važni i u javnom i u privatnom životu.

Čitajući Govornika, djelo najvećega rimskoga govornika Marka Tulija Cicerona, dobivamo dojam da je način govorenja, tj. emocije i osjećaji govornika u trenutku govorenja, najvažniji u procesu prenošenja istine publici jer $\gg$ kao da snaga i učinci govora potpuno ovise o uvjerenju kojim zrači govornik u trenutku teatralizacije istine $\ll^{20}$. Ciceron drži da se epideiktički govori izvode u neformalnim situacijama i trenutcima zabave jer smatra da ih je užitak slušati. U epideiktičke vrste ubraja elegije, različite opise, povjestice, budnice poput Izokratova Panegirika i mnoge govore koje su sofisti ranije izvodili. Karakteristike su epideiktičkoga stila urednost i jednaka duljina rečenica, a ukrašavaju se prema prigodi bez unaprijed određenoga stila. $\gg$ Epideiktički je govor sladak, tečan, obilatog stila. $S$ blistavim zamislima i zvučnim frazama. Plodno je polje za sofiste i pogodniji je za paradu, nego za bitku. $\ll{ }^{21} \mathrm{U}$ ranim početcima Rimskoga Carstva pronalazi se najveći korpus latinske epideiktike poznat pod nazivom Latinski panegirici. Većina formalnih panegirika bili su pogrebni (laudationes funebres) ili pohvalni govori (gratiarium actiones) izvođeni uglavnom kako bi pohvalili rimske konzule. Međutim epideiktički su se govori također izvodili u prigodama slavlja različitih obljetnica, carskih vjenčanja, obljetnica postojanja grada Rima itd. ${ }^{22} \mathrm{U}$ tom su razdoblju postojale tri vrste stila, niski (obični), srednji i visoki (uzvišeni), koje su bile usko povezane s trima duž-

\footnotetext{
${ }^{18}$ Usp. J. GRGIĆ, Platon - Gozba ili O ljubavi, u: Nova akropola, br. 61, Zagreb, http://www.novaakropola.com (19. 5. 2018.).

${ }^{19}$ Isto, 43.

${ }^{20}$ M. MEYER i dr., Povijest retorike od Grka do naših dana, 53.

${ }^{21}$ R. NORDQUIST, Definition and Examples of Epideictic Rhetoric, http://www.thoughtco.com, (19. 5. 2018.).

${ }^{22}$ W. DOMINIC, J. HALL, A Companion to Roman Rhetoric, Blackwell, 2010., 144.
} 
nostima govornika: podučavati publiku (probare, docere), oduševiti publiku (conciliare, delectare) i emotivno ju taknuti (movere, flectere). Visoki stil pogodan je za epideiktičke govore i dijelove epideiktičkih govora jer je retorika u tadašnje vrijeme više zahtijevala vanjsku formu, tj. ukrašenost govora tropima i stilskim figurama koje su pridonosile osjećaju elegancije pri izvođenju govora više od gramatičke forme. ${ }^{23}$ Osim toga iz 66. g. pr. Kr. datira govor Pro Lege Manilia u kojem Ciceron iskazuje podršku rimskom senatoru Maniliju. Treba spomenuti i njegov govor Pro Marcello (Za Marcelija), čija je struktura najbliža strukturi epideiktičkih govora, a sam govor svojevrsni je panegirik Cezaru.

Jedan od najpoznatijih kršćanskih učitelja koji je živio između 4. i 5. st. zasigurno je sveti Augustin. Nakon preobraćenja na kršćanstvo u svojim je djelima kritizirao retoriku kao puku elokvenciju kojoj je cilj zadiviti publiku. No smatrao je da elokvencija može biti korisna u propovijedanju. »Retorika, koja se u prvom redu poima kao ars praedicandi (umijeće propovijedanja), smatra se legitimnom kad joj je cilj kršćanska istina, a nelegitimnom kad se zbog pogrešaka ili ljudske gluposti taj uzvišeni cilj ignorira. ${ }^{24}$ Međutim sv. Augustin ne govori o epideiktičkim vrstama govora, već je njegov rad ponajprije usmjeren na homilije. Iako su epideiktički govori u kršćanskom razdoblju rijetki, u 6. st. prevladavaju carski (imperijalistički) govori. Najpoznatiji je onaj Euzebija Cezarejskog Vita Constantini, svojevrsni panegirik, kojim se, umjesto iznošenja suhoparnih podataka o životu cara, hvale i idealiziraju njegovi uspjesi.

Što se tiče renesansnoga razdoblja, u kontekstu epideiktičkih govora, treba spomenuti francuskoga jezuita Nicolasa Caussina (1583. - 1651.) koji od svih retoričkih žanrova posebnu pozornost posvećuje upravo epideiktičkom govorništvu. U djelu Epideikticki govori navodi popis tema koje ubrajamo u epideiktičke govore, pozivajući se pritom na djela antičkoga retoričara Dionizija iz Halikarnasa. Proučavajući njegove primjere i upute za pisanje pisama, Caussin navodi teme poput rođenja ili epitalamija $^{25}$, pogrebnih govora, zahvala i zdravica. Smatra kako je mnogo uputa slično onima Menandera Rhetora, grčkoga retoričara koji je napisao dvije nepot-

${ }^{23}$ Isto, 193.

${ }^{24}$ I. PRANJKOVIĆ, Bene dicendi scientia. Michel Meyer, Benoît Timmermans i Manuel Maria Carilho, Povijest retorike od starih Grka do naših dana (Disput, Zagreb, 2008.), Prikaz knjige, u: Fluminensia 21(2009.) 1, 225-230.

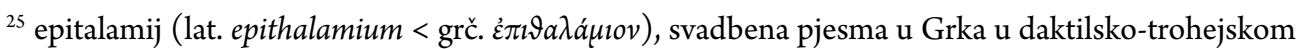
ritmu. Izvodili su je mladići i djevojke pred bračnom odajom, kada su otpjevane pjesme na gozbi (gamelij) i one na putu do doma mladenaca (himenej). Poznatiji su autori epitalamija Sapfa (sačuvani samo fragmentarno), Alkej, Teokrit i Katul te potom T. Tasso, G. Marino, P. de Ronsard, R. Belleau, J. Donne i E. Spenser. Postoji i cijela zbirka epitalamija iz rimskoga carskoga doba. (http:// wwww.hrleksikon.info, datum posjeta: 18.5.2018.) 
pune rasprave o epideiktičkim govorima. ${ }^{26}$ Razlike između statusa epideiktičkih govora u grčkoj i rimskoj antici, kao i spomenute rasprave Menandera Rhetora, dovele su do zaključka da kasna renesansna retorika stavlja veći naglasak na epideiktičke govore nego što je to bio slučaj u rimskoj antici. ${ }^{27} \mathrm{U}$ to vrijeme dolazi do sukoba između tzv. ciceronovaca i anticiceronovaca, odnosno do sukoba patosa (pa možemo reći i epideiktičkoga žanra) kojem je cilj uzvišenost i stvaranje užitka te etosa (deliberativnoga žanra) kojem je cilj korisnost.

U idućim stoljećima dolazi do pada ugleda retorike, a samim time i manje važnosti epideiktičkih govora. Prema riječima G. Genetta ${ }^{28}$, francuskoga književnoga kritičara, to je razdoblje obilježio proces restrikcija na polju klasične retorike koji je započeo u srednjem vijeku, a možda čak i u kasnom antičkom razdoblju. Međutim talijanski vjerski reformator Pier Paolo Vergerio (1498. - 1565.) u svojoj raspravi De ingenius moribus smatra da je epideiktika jedini žanr koji je preživio sve do današnjih vremena. Epideiktika je bila važna u oblikovanju javne elokvencije koja je zbog tadašnjih okolnosti praktički bila ograničena na svečane prigode. Osim toga epideiktička formula primjenjivala se i u književnoj praksi zbog svoje »moralno angažirane, stilski ispolirane i često snažne emotivne retorike $\ll^{29}$.

\section{Suvremena retorika i epideiktički žanr}

Suvremeni autori retorike 20. i 21. stoljeća rjeđe su se bavili problematikom epideiktičkoga žanra, a više pozornosti posvećivali su drugim dvjema vrstama retorike sudskoj i deliberativnoj. Mogući razlog tomu jest povezivanje epideiktičkoga govora više s književnošću, stilom i stilistikom, što potječe još od srednjega vijeka, a manje s filozofijom, logikom i argumentacijom. Smatralo se da taj žanr pripada drugim sferama interesa, a ne toliko retorici. Lantham piše: $\gg$ Epideiktička retorika, odnosno retorika 'pohvala i pokude' uvijek mi je predstavljala klasifikacijski problem. Za početak, ono što se nazivalo epideiktičkim često se u antici prakticiralo i u političkim forumima i u sudnicama. I nije li termin 'pohvala' nekompatibilan terminima 'pravno' ili 'sudsko' koje impliciraju mjesto događaja i društvenu funkciju. Da bi bilo kompatibilno, trebalo bi zvučati 'privatno', no ni to se ne uklapa. Možda je najbolje shvatiti taj žanr, slijedeći Aristotela, kao 'ceremonijalan' (...) Možda bismo mogli reći kako su deliberativni i sudski govori svrhoviti, a epideiktički zabavljački? « ${ }^{30}$

\footnotetext{
${ }^{26}$ P. MACK, A History of Renaissance Rhetoric, New York, 2017., 205.

${ }^{27}$ Isto, 313.

${ }^{28}$ Usp. I. WORHINGTON, A Companion to Greek Rhetoric, Malden, 2007., 75.

${ }^{29}$ Usp., W. COX, J. O. WARD, The Rhetoric of Cicero in Its Medieval and Early Renaissance Commentary Tradition, Boston, 2006.,130.

${ }^{30}$ Usp. R. LANTHAM, A Handlist of Rhetorical Terms, Berkley, 1991., 164.
} 
Nemogućnost da se epideiktički žanr simetrično odredi u odnosu na sudski i deliberativni, nedostatak svrhovitosti i društvene relevantnosti, nepostojanje potrebe za logikom i argumentiranjem, dominantnost stila i uzvišene izvedbe, mogući su razlozi zbog kojih se taj žanr u suvremenoj retoričkoj teoriji zanemaruje.

Revoluciju u suvremenom poimanju retorike izazvali su Chaïm Perelman i Lucie Olbrecht-Tyteca ${ }^{31}$ koji epideiktičke govore smatraju ključnima jer se epideiktičkim govorima privrženost publike prema određenim vrijednostima (u koje već vjeruju) može pojačati, tj. intenzivirati te se na taj način stvara temelj za buduće djelovanje političkih i sudskih govornika. U knjizi The New Rhetoric: A Treatise of Argumentation Perelman i Olbrechts-Tyteca ističu kako epideiktika predstavlja žanr koji se najviše bavi vrijednostima i koji je u odnosu na političke i sudske govore zanemaren zbog pogrješnoga shvaćanja Aristotelova objašnjenja da estetski kriterij predstavlja primarni kriterij takvoga diskursa. Autori smatraju da epideiktički diskurs nije sporedan, već »čini središnji dio umijeća uvjeravanja « i namijenjen je »jačanju sklonosti prema djelovanju kroz povećanje prihvaćanja vrijednosti koja pohvaljuje «.32 Perelman i Olbrecht-Tyteca ${ }^{33}$ ističu kako se epideiktički žanr razlikuje od političkih ili sudskih debata jer govornik iznosi govor $\gg$ kojem se nitko ne protivi, temu koja nije kontroverzna i nema nikakvih praktičnih posljedica «. Iz toga proizlazi kako bismo epideiktički žanr prije povezali $s$ književnošću (kao što je to bio slučaj u srednjovjekovnoj retorici) nego $s$ argumentacijom. Međutim autori pišu ${ }^{34}$ : $\gg$ Prema našem mišljenju epideiktičko govorništvo je centralni dio umijeća uvjeravanja. A to što je to bilo zanemareno rezultira iz pogrešnog poimanja učinka argumentacije.« I upravo je novo viđenje argumentacije i razlog zbog kojega se Perelman i Olbrecht-Tyteca bave tim, pomalo zaboravljenim i marginaliziranim govorničkim žanrom. Upozoravaju međutim ${ }^{35}$ : $\gg$ To je jedina vrsta govorništva koja podsjeća na književnost, jedina vrsta govorništva koja se može usporediti s libretom u operama, i ona kojoj najviše prijeti opasnost da se pretvori u deklamaciju i da postane ona uobičajena retorika u pejorativnom smislu riječi. (...) Takva se vrsta govorništva najčešće povezuje s govornicima usmjerenima na obranu i očuvanje tradicionalnih vrijednosti, a ne s novim, revolucionarnim ili kontroverznim stavovima koje bi uzburkale javnost i izazvala polemike.«

\footnotetext{
${ }^{31}$ C. PERELMAN, L. OBLRECHT-TYTECA, The New Rhetoric: A Treatise of Argumentation, London, 1969.

${ }^{32}$ Usp. A. G. GROSS, R. D. DEARIN, Chaim Perelman, New York, 2003., 154.

${ }^{33}$ Isto, 48.

${ }^{34}$ Isto, 49.

${ }^{35}$ Isto, 51.
} 
$\mathrm{Na}$ kraju autori zaključuju: $\gg \mathrm{U}$ epideiktičkom žanru, govornik zapravo postaje poučavatelj. $\ll^{36}$

Gross i Dearin ${ }^{37}$ kao primjer izvrsnoga epideiktičkoga govora navode posmrtni govor Earla Spencera koji je izveo na sprovodu svoje sestre princeze Diane. U svakom se dijelu govora ističu moralne vrijednosti, hrabrost, važnost i veličina princeze Diane, a epideiktički govor mora biti upravo takav.

U svojoj studiji o epideiktičkom govorništvu Epideictic Rhetoric: Questioning the Stakes of Ancient Praise, objavljenoj 2015. godine, L. Pernot ${ }^{38}$ smatra kako je pojam epideiktičkih govora još od Aristotelova vremena jako slabo definiran i prepun nejasnoća.

Herrick $^{39}$ naglašava činjenicu da uvijek kada razmišljamo o nečemu što smatramo dobrim i hvalevrijednim, razmišljamo na epideiktičan način. U svojoj knjizi predstavlja i svojevrsni epideiktički diskurs koji se događa kada npr. sportski novinar hvali uspješnoga sportaša pišući o njegovim pobjedama i medaljama koje je osvojio, a mi o tome čitamo. No postoje slučajevi kada se epideiktički govor ne može promatrati kao zasebna vrsta govora. Ponekad se epideiktički govor pojavljuje i u sklopu drugih vrsta govora. Kao primjer navodimo poznati govor M. L. Kinga I have a dream, gdje su osim elemenata političkoga govora, zastupljeni i elementi epideiktičkoga govora. U svom govoru on zastupa vrijednosti pravde, mira i sklada i iz toga ga razloga, po Herricku, možemo promatrati u okviru epideiktičkih govora. U primjerima sudskih govora često nailazimo na epideiktičke elemente jer se sudskim govorima želi dokazati nečiju nevinost ili krivnju djelujući na emocije publike (sudca, porote...).

\section{Epideiktički žanr u suvremenoj kršćanskoj retorici - retorička analiza božićnih poruka biskupa}

Svećeničke propovijedi i religijski diskurs općenito uobičajeno sadržavaju elemente epideiktičkoga žanra ističući vrijednosti, vrline koje bi svaki vjernik trebao slijediti. Međutim čini se kako su najbolji primjeri Aristotelova poimanja epideiktičkoga žanra s elementima deliberativnoga upravo božićne poruke. To su govorničke vrste kojima se biskupi obraćaju vjernicima čestitajući Božić, ali i odašiljući poruke o važnosti ne samo toga dana već i kršćanskoga nauka i načina života. Božić označava početak novoga života, kraj jedne i početak iduće godine pa se i samim vremenom

\footnotetext{
${ }^{36}$ Isto, 52.

${ }^{37}$ A. G. GROSS, R. D. DEARIN, Chaim Perelman, New York, 2003., 148.

${ }^{38}$ L. PERNOT, Epideictic Rhetoric: Questioning the Stakes of Ancient Praise, Austin, 2015.

${ }^{39}$ J. HERRICK, History and Theory of Rhetoric, 80.
} 
govora vjernike upućuje na promjene, odbacivanje nekih starih, a usvajanje novih obrazaca ponašanja. Dakle božićne poruke, retorički gledano, bile bi svojevrsno sjecište epideiktičkoga i deliberativnoga žanra. Aristotel (1368a6) je rekao: »Ako namjeravaš hvaliti, razmisli što time potičeš, ako namjeravaš poticati, razmisli koje ćeš osobine hvaliti.«

Pri analizi božićnih poruka hrvatskih biskupa 2015. i 2016. godine primijećene su retoričke karakteristike i delibarativnoga i epideiktičkoga govorništva. Analiziralo se pet biskupa, kao i božićna poruka kardinala Bozanića, a njihove su poruke dostupne na službenim YouTube kanalima biskupija. Cilj analize bio je opisati retoričke specifičnosti božićnih poruka kao jednoga posebnoga žanra u kršćanskoj retorici.

Valja napomenuti kako je Katolička Crkva 2016. godinu proglasila godinom milosrđa (od 8. prosinca 2015. do 20. studenoga 2016.), pa se pretpostavljalo kako će upravo milosrđe, solidarnost i samilost biti osnovne vrijednosti koje će se naglašavati u božićnim porukama. Također valja u obzir uzeti i društveno-političke okolnosti toga vremena koje su zacijelo utjecale na sadržaje poruka (2015. bila je godina u kojoj se Hrvatska suočavala s migrantskom krizom, ekonomskom, gospodarskom i političkom postizbornom krizom).

\subsection{ELEMENTI EPIDEIKTIČKOGA ŽANRA U BOŽIĆNIM PORUKAMA}

Kao što je prethodno spomenuto, epideiktički retorički žanr ističe i hvali određene vrijednosti, a u neki slučajevima kudi poroke i osuđuje određene vrste ponašanja. Kao primjer možemo istaknuti božićnu poruku kardinala Josipa Bozanića.

(https://www.youtube.com/watch?v=xl0xQehmE3E)

Vrijednosti koje ističe jesu ljudskost, čistoća duha, spoznaja Boga, Božje milosrđe, ljudsko dostojanstvo, a iznosi i tvrdnju kako se prava ljepota ne može mjeriti kriterijima fizičke ljepote, već ona dolazi iznutra, prava ljepota jest ljepota duha. Epideiktički žanr karakterizira i iznošenje tvrdnji koje bi se u deliberativnom žanru (ili nekom drugom diskursu) smatrale trivijalnima. Međutim epideiktički žanr ne zahtijeva argumentaciju, već uvjeravanje temelji na amplifikaciji (korištenje raznim stilskim sredstvima kako bi se tvrdnja intenzivirala, učvrstila u stavovima slušatelja). Ono na čemu se temelji persuazivna snaga ove poruke nije dakle argumentacija, već naracija. I upravo je naracija osnovno retoričko sredstvo kojim kardinal Bozanić prenosi poruku: cijela povijest čovječanstva bila je obilježena potragom za Bogom.

Kardinal Bozanić, osim što hvali, kritizira eksplicitno ili implicitno neke osobine suvremenoga čovjeka (osobito onoga na vlasti). Nedostatak hrabrosti i sigurnosti da se riješe problemi, nedostatak odlučnosti onih koji bi narodu trebali osigurati sigurnost. 
Slični retorički obrasci prisutni su i u božićnim porukama biskupa. Hvale se tradicionalne vrijednosti kršćanskoga života: obitelj, solidarnost, milosrđe, zajedništvo; a kritiziraju se iskrivljene vrijednosti nametnute suvremenim životom: trčanje za novcem, profitom, ignoriranje Boga (npr. Marin Barišić).

(https://www.youtube.com/watch?v=QUOpI3J1brg\&list=PLsL6gZSaflG6Ry_ i8rSNlgKFF7JExwKma\&index $=5 \& \mathrm{t}=0 \mathrm{~s}$ )

Biskup Vlado Košić (https://www.youtube.com/watch?v=79D_-ljLkLA) svojom božićnom porukom kritizira komercijalne i konzumerističke vrijednosti Božića (Božić nije gledanje pod bor i traženje poklona), a uzvisuje one istinske, kršćanske (srce ispunjeno Božjom ljubavi). Čitav je niz osobina koje se uzvisuju i veličaju njegovom porukom: istina i istinoljubivost, skromnost i poniznost, iskrenost i poštenje.

\subsection{ELEMENTI DELIBERATIVNOGA ŽANRA U BOŽIĆNIM PORUKAMA}

Deliberativni žanr, za razliku od epideiktičkoga, potiče na akciju, na promjene. Usmjeren je budućnosti, savjetodavan je, ima jasne tvrdnje, obrazloženja, a prema Aristotelu najčešći oblik argumentacije u tom žanru jest korištenje primjerima. Još jednom valja spomenuti poruku kardinala Bozanića koji iznosi tvrdnju i na akciju potiče političke elite koje bi trebale raditi na tome da poboljšaju život građana. A iznosi i niz primjera problema s kojima se suvremeni čovjek suočava: siromaštvo, nesigurnost, loši demografski trendovi i iseljavanje stanovništva, a sve to vodi i do krize braka i obitelji, urušavanja tradicionalnih vrijednosti te konflikata u društvu. Eksplicitno se obraća političkim elitama i traži ih da prestanu s eksperimentiranjima koja ugrožavaju budućnost ljudi u Hrvatskoj, da probude svoju savjest i pomognu vraćanju mira.

Sličnoga sadržaja jest i božićna poruka biskupa Đure Hranića (https://www.youtube.com/watch?v=TGjd2kRa5r8) koji navodi niz problema koji se moraju riješiti da bi čovjek u Hrvatskoj mogao dostojanstveno živjeti, a to su dužničko ropstvo (moderno ropstvo bankama i kreditima), odlazak mladih ljudi iz zemlje, demografska kriza.

Također su u božićnim porukama česta implicitna ili eksplicitna referiranja na aktualne događaje koji se (ponajviše) kritiziraju (što pripada epideiktičkomu žanru), ali se potiče na promjene. Primjerice biskup Marin Barišić potiče na promjene $u$ shvaćanju braka u suvremenom društvu, smatrajući da je poimanje braka i njegova svetost narušena društvenim promjenama: Brak je zajednica muškarca i žene koja je ugrožena nekim drugim oblicima zajednice. Također navodi na promjene u poimanju obiteljskih uloga u suvremenoj obitelji u kojoj nerijetko dolazi i do umanjivanja važnosti oca te nesposobnosti da se preuzme ta odgovorna uloga, a sve zbog problema 
s kojima se građani suočavaju ( $\gg$ Otac kao da je postao sporedan i suvišan. $\ll$ ). Obitelj koja je, prema riječima biskupa Barišića, »temeljna stanica društva i Crkve, susreće se s mnogim poteškoćama i raznim iskušenjima «. Navodi niz primjera koji su do toga doveli: gospodarska kriza, gubitak radnih mjesta, nesposobnost suočavanja s izazovima života, manjak komunikacije u obitelji, prepuštanje relativizmu. Uz to na poimanje obitelji utječu razne »idejne struje i društveni trendovi koji žele rastočiti naravno shvaćanje braka i obitelji.« Biskup Barišić potiče na promjene, a za koje snagu i hrabrost može dati Bog, potiče na očuvanje tradicionalnih obiteljskih vrijednosti kojima se treba vratiti (»Gramatika zajedništva, pravopis ljubavi.«).

Biskup Hranić (https://www.youtube.com/watch?v=TGjd2kRa5r8\&t=27s), govoreći o problemima suvremenoga čovjeka, ističe nadu da će one koji imaju političku vlast primjer Božjega milosrđa potaknuti na snažnije zauzimanje za opće dobro.

\subsection{BOŽIĆNE PORUKE KAO POSEBAN RETORIČKI ŽANR}

Božićne poruke po mnogim su retoričkim elementima posebna govornička vrsta. Odlikuju se dominantno karakteristikama epideiktičkoga žanra jer ističu vrijednosti koje valja usvojiti i slijediti, a kritiziraju poroke, slabosti i sve one loše strane društva kojima je izložen suvremeni čovjek. Međutim nerijetko sadržavaju implicitne ili eksplicitne deliberativne poruke, pa i argumentaciju primjerenu tomu žanru.

Karakteristična za epideiktički žanr, božićne poruke odlikuje velika pozornost koja se posvećuje stilu: bogata figurativnost, viši jezični i govorni stil. Najěešća stilska sredstva božićnih poruka jesu metafore, čija je osnovna funkcija upravo pojačavanje dojma i persuazivne snage. Naime poznato jest da se figurama koristimo kako bismo govoru dali boju, stvorili interes, pobudili maštu. Jaffe ${ }^{40}$ ističe kako figurativan jezik slušaču omogućuje stvaranje mentalnih slika riječi i ideja, a mnoge figure pomažu govor učiniti zanimljivijim: aliteracije, ponavljanja, personifikacije, metafore i usporedbe, figurativne analogije, hiperbole... Upravo je metaforičnost izraza osnovna retorička karakteristika božićnih poruka, pri čemu se one razlikuju od običnih propovijedi. Naime Osborn govori: »Metafore aktiviraju motivacijsku energiju publike i u tome leži njihova persuazivna moć. Zbog moći uvjeravanja retoričar će metaforu koristiti kada želi potaknuti društvene promjene, kada želi da njegov govor ostane dugo u sjećanju publike. ${ }^{41}$ I imajući upravo to na umu, božićne poruke biskupa obiluju metaforama: umirovljenici su se prignuli pod teretom životnih tegoba, ljudi su upali u okove beznada, suočeni smo sa zlogukim osjećajem zebnje, treba otvoriti

\footnotetext{
${ }^{40}$ Usp. C. JAFFE, Public Speaking - Concepts and Skills for a Diverse Society, Boston, 1998.

${ }^{41}$ M. OSBORN, Public Speaking, Boston, 1997., 115.
} 
srce nadi, prihvatiti dar prijateljstva, izbjeglice bježe od suvremenih Heroda, podlegnuti moći novca i korupcije, potkopava temelje društva, pohlepa gazi siromašne...

Osim metafora česte su usporedbe (milosrđe je poput anestezije koja pomaže umanjiti bol), antiteze (u obitelji Božić ne proizvodi, nego rađa, ne čini, nego prima; pravednost bez milosrda postaje osveta), figurativne analogije s biblijskim motivima (suvremene obitelji traže izlaz poput svete obitelji koja je bježala u Betlehem; kako bi rijeka tekla bez svog izvora, kako bi valovi postojali bez mora, kako bi čovjek bio spreman činiti hrabra djela bez Božje ljubavi).

Jedna od specifičnosti božićnih poruka jest i retorička publika. Naime epideiktički žanr uobičajeno nudi teme koje su nekontroverzne, nediskutabilne, s kojima se u načelu svi slažu. Govornik kod publike treba samo produbiti ili intenzivirati vrijednosti s kojima se ona slaže. Deliberativni žanr usmjeren je publici koja treba donijeti odluke o nekom pitanju i poduzeti korake. I u tom segmentu, retoričke publike, božićne poruke su na svojevrsnom raskrižju. Usmjerene su vjernicima (koji slave Božić), djelomično nevjernicima (onima koji sumnjaju), ali i onima koji su dio političkih elita, koji su na vlasti. Upravo zbog heterogenosti publike vrlo je važno koristiti se retoričkim postupcima kako bi poruke došle do svih i kako bi svi imali osjećaj da su upućene njima. Stoga se nerijetko koristimo prolepsom, retoričkom figurom kojom se anticipiraju prigovori koji se odmah zatim pobijaju (postoje oni koje naša vjera zbunjuje, ali ....). Isto tako koristimo se taktikama kojima se jaz između onih koji vjeruju i slave te onih koji ne obilježavaju Božić smanjuje. Tako uvod počinjemo rečenicama: Onima koji slave Božić i svim ljudima dobre volje. Time se naglašava zajedništvo u božićnome vremenu i poruka usmjerava i onima koji se ne smatraju vjernicima (ali smatraju se ljudima dobre volje).

\section{Zaključak}

Iako bi se prvim, ponešto površnim, pogledom na današnju retoriku moglo zaključiti kako je epideiktičko govorništvo nešto što pripada povijesti, a ne suvremenom društvu, valja istaknuti da je ono i danas uvelike prisutno te mu je i u podučavanju retorike i u retoričkoj analizi potrebno posvetiti pozornost. I u kršćanskoj retorici, ali i u svakodnevnom javnom diskursu kada se god nešto ili netko hvali, uzvisuje ili kada se kritizira, ulazi se u sferu epideiktičkoga govorništva.

Komemorativni govori, inauguracijski ili motivacijski u sebi sadržavaju elemente epideiktičkoga žanra. I gotovo svi profesionalni javni govornici prije ili kasnije susreću se s potrebom da hvale ili kude, uzvisuju ili kritiziraju, uključuju vlastite osjećaje u teme svojih govora kako bi pobudili osjećaje svoje publike.

Svećenici su vrlo često u prilici upravo isticati vrline i moral, a osuđuju grijeh i poroke, a samim time njihove riječi često su primjer upravo epideiktičkoga žanra. Bo- 
žićne poruke o kojima se govorilo u ovome radu predstavljaju posebnu govorničku vrstu u kojoj se isprepliću epideiktički i deliberativni žanr, naglašavaju se kršćanske vrijednosti, a ljude se potiče na promjene. Klasični retorički termin kairos posebno je važan jer Božić simbolizira početak novoga života, a uz to kalendarski završetak jedne, a početak iduće godine, obično je vrijeme kada se odlučujemo na promjene. I upravo zbog toga biskupi u svojim božićnim porukama uz ceremonijalne retoričke elemente čestitanja Božića navode vjernike, ali i one koji to nisu, na donošenje odluka, na promjene u ponašanju i stilu života, na promjene u poimanju svijeta $\mathrm{i}$ društva.

Epideiktičko je govorništvo kroz povijest bilo važan (u nekim razdobljima i jedini) način izgradnje vrijednosti u čovjeku i društvu. Od vremena antičke Grčke pa sve do suvremenoga doba, vrijednosti, vjerovanja, vrline i moral prenosili su se epideiktičkim žanrom. I upravo zbog toga, u vremenu kada su informacije lako dostupne, kada se do gotovo svih podataka, činjenica (točnih ili ne) može doći s nekoliko klikova na računalu, izgradnja moralnoga društva i dalje dominantno počiva na govoru. I to na epidiktičkome govoru. 


\title{
THE IMPORTANCE OF EPIDEICTIC GENRE IN CLASSICAL AND CONTEMPORARY RHETORIC (ON THE EXAMPLE OF THE ANALYSIS OF CHRISTMAS MESSAGES OF CROATIAN BISHOPS)
}

\author{
Gabrijela KIŠIČEK*
}

Summary: The paper presents an overview of the historical development and importance of the epideictic genre in rhetoric. Aristotle divided rhetoric into deliberative, judicial and epideictic, distinguishing between them according to their end goal, according to the means of argumentation, according to the dominant means of persuasion, and according to temporal orientation (deliberative rhetoric is directed to the future, judicial to the past, and epideictic to the present). The paper presents the rhetorical specificities of the epideictic genre and emphasizes the importance and value of this type of speech in both classical and modern rhetoric. As an example of current presence of epideictic rhetoric, Christmas messages of Croatian bishops are analyzed in order to show on concrete examples how epideictic speaking looks in contemporary practice, and at the same time Christmas messages are described as one specific and special type of Christian rhetoric.

Keywords: epideictic rhetoric, deliberative rhetoric, pathos, Christmas messages.

\footnotetext{
* Asst. Prof. Gabrijela Kišiček, Ph. D., University of Zagreb Faculty of Humanities and Social Sciences, Ivana Lučića 3, 10000 Zagreb, gkisicek@ffzg.hr
} 